\title{
Using LIDAR topography data for determination of morphology and terrace levels of the River Ogre Valley in Middle Latvia Lowland
}

\author{
Janis Ivanovs, Maris Krievans \\ University of Latvia, Department of Geography; Jelgavas 1, LV-1004 Riga, Latvia; \\ e-mail: janis.fon.ivanovs@gmail.com, maris.krievans@lu.lv
}

(C) 2016 Authors. This is an open access publication, which can be used, distributed and reproduced in any medium according to the Creative Commons CC-BY 4.0 License requiring that the original work has been properly cited.

Development of the geodetic and remote sensing techniques in the last decade makes it possible to carry out detailed geomorphological studies and acquire a high quality geospatially accurate data. One of the latest technologies available for collecting topography data is Light Detection and Ranging (LiDAR) which uses fast-firing laser to measure distances from small aircraft to the surface of the earth (Bowen et al. 2002).

The study area occupies the Middle Latvia lowland. Previous studies of the River Ogre valley has been made in 1970s (Eberkhard 1972). Recent studies have been carried to supplement information of the distribution of river terraces. Riverbed of the River Ogre valley in Middle Latvia lowland is mostly straight or meandering, with individual branched stages. Valley width mostly ranging from $250 \mathrm{~m}$ to $500 \mathrm{~m}$, while in some stages width is only $100 \mathrm{~m}$, while in others reaches up to $1400 \mathrm{~m}$.

For this study, classified LiDAR data in ASCII format have been acquired from Latvian Geospatial Information Agency. Digital elevation model (DEM) with raster cell size $1 \times 1 \mathrm{~m}$ has been made using Global Mapper v15 software. DEMs with raster cell size $0.5 \times 0.5 \mathrm{~m}$ and $2 \times 2 \mathrm{~m}$ have been also made, however DEM with raster cell size $1 \times 1$ $\mathrm{m}$ was assessed as optimal, because the amount of data and information processing time, as well as terrain data quality is sufficient to achieve the objective. Such a choice of raster cell size is also based on other studies (Wheaton et al. 2010, Brasington et al. 2012).
Longitudinal profile of the River Ogre has been made using DEM and is based on more than 400 valley cross profiles. The longitudinal profile consists of all of detected fragments of terraces, floodplain and elevation of valley margins.

To ensure that the DEM is accurate, field observations were carried out and several terraces and shorelines of Quaternary palaeolakes were detected. For example, Zemgale palaeolake shoreline associated with River Ogre valley Ranka spectrum IV terrace, which is visible in the nature and clearly traced on elevation model.

The obtained results show that six different terrace levels of Ranka spectrum were detected. I, II, and III terraces are related to levels of the River Daugava terraces, IV terrace is related to Zemgale paleolake but V and VI terrace is linked to various water levels of Daudzeva paleolake.

\section{REFERENCES}

Bowen Z.H. \& Watermire R.G., 2002. Evaluation of Light Detection and Ranging (LIDAR) for Measuring River Corridor Topography. Journal of the American Water Resources Association, 38, 1, 33-41.

Brasington J., Vericat D. \& Rychkov I., 2012. Modeling river bed morphology, roughness, and surface sedimentology using high resolution terrestrial laser scanning. Water Resources Research, 48, 11, 1-18.

Eberkhard G.Ya., 1972. Stroyeniye i razvitiye dolin basseyna reki Daugava. Zinatne, Riga.

Wheaton J.M., Brasington J., Darby S.E. \& Sear D.A. 2010. Accounting for uncertainty in DEMs from repeat topographic surveys: improved sediment budgets. Earth Surface Processes and Landforms, 35, 2, 136-156. 